\title{
VERSITA
}

Ekológia (Bratislava)

Vol. 32, No. 4, p. 383-387, 2013

doi:10.2478/eko-2013-0036

\section{INFRARED IMAGES AND LAND COVER IN THE PAST}

\author{
VÁCLAV ŽDÍMAL
}

Mendel University in Brno, Zemědělská 1, 61300 Brno, Czech Republic; e-mail: zdimal@mendelu.cz

\begin{abstract}
Ždímal V.: Infrared images and land cover in the past. Ekológia (Bratislava), Vol. 32, No. 4, p. 383-387, 2013.

Czech landscape is an old residential area used by humans since ancient times. At one point, we can follow the traces of human activity from different periods and natural changes. Land cover of one location can change several times. The most important reason is meandering and subsequent straightening of rivers, deforestation, relocation and change in soil layers. These changes in the past affect the present management, and it is important to identify them. A suitable tool for the determination of different sites is remote sensing in the infrared spectrum, which monitors changes in the vegetation, with the support of archival materials. These changes in vegetation are statistically significant and distinct sites with different histories of others. After identifying the different places, one can search the archive materials to know what was the land cover in the past. The following archival materials have been used: maps II and III, military mapping, basic maps and other maps and historical aerial photographs. These images document the landscape before collectivization and the reclamation of the land, which dynamically changed the landscape cover. The studied area was documented by other aerial photographs from other time periods between 1959 and 1989 and mainly infrared images from present were used as the main basis for determining the development of land cover. A comparative analysis of land cover shows the increases and decreases in agricultural land, changes in communication line elements, the impact of new methods of land use, erosion control restoration measures, changes in retention capacity, losses and increase forest, comparing the legal and actual status of the forest boundaries and their changes over time and changes in the built areas.
\end{abstract}

Key words: remote sensing, infrared image, land cover changes.

\section{Introduction}

The landscape is constantly changing. The causes of these changes are both natural and manmade, but nowadays mostly human. In developed countries with dense settlement, there is a great pressure on the landscape and are many people interested in its use. Czech landscape belongs to the old development areas used by humans since ancient times. The landscape has been under human influence since people first arrived on the scene, with individual eras leaving their mark in the form of layers which may be read almost like a palimpsest. A single location may show evidence of human activity for different periods and natural changes. The land cover of one location could change several times. The most important reason is meandering and subsequent straightening of rivers, deforestation and soil movement. In the past, those changes influenced today's management and it is important to identify them. When we design a new land use, it is important to know the land cover in the past. Knowledge of 
the land cover in the past allows us to propose the appropriate land use in the present and prevent unsuitable use of landscape with limited usage. One of the tools used to determine the different places are remote sensing in the near-infrared band monitoring the vegetation changes. These changes show the vegetation places with different histories of others. After identifying the different sites, the land cover in the past can be found in archival materials.

Lipský (1999) and Kubeš (1996) describe detailed origin and development of cultural landscape in the Czech Republic. Czech landscape underwent a fundamental change in the period of socialist collectivization of agricultural production since 1954. The area of agricultural land increased, and meadows and grassland were arable in the lower altitudes. Increasing the area of agricultural land and the change of management of the meadows and pastures have deteriorated aesthetic parameters of the countryside. In some areas, there was an increase in the area of the woody vegetation of agricultural landscape in the period of socialist collectivization of agriculture. That development was different in each territory of the republic, depending on whether it was a production area or marginal. Large-scale socialist farming practices in the country left a number of small unusable areas with weeds and trees. The current state of the landscape is not very different from the condition of the landscape during periods of maximum application of forms of socialist agriculture. Examples of simplification of the landscape microstructure are shown in Figs. 1 and 2.

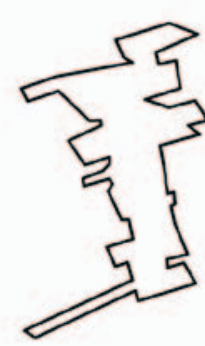

1953

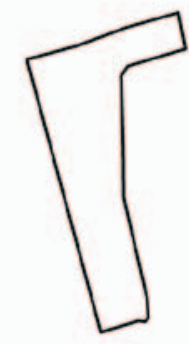

2010

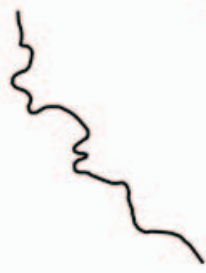

1878

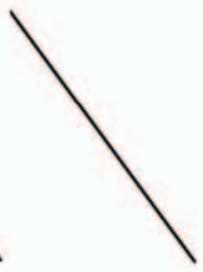

2010

0 250 Meters

Fig. 1. Simplification of forest.

Fig. 2. Straightened river Šatava.

Spectral characteristics of plants are the main consequences of the different land use. The spectral behaviour of vegetation showed a significant increase in reflectance in the near-infrared spectrum. It is commonly stated that in the visible spectrum, about $20 \%$ of incident radiation is reflected by vegetation, while in the near-infrared spectrum about $60 \%$ is reflected. The difference in the amount of chlorophyll in leaves has a great influence on the determination of leaf area index LAI. Influence of the amount of chlorophyll on the LAI determination was studied by Haboudane et al. (2004). Convenience of used spectral bands is often a discussed question. Primary, standard red (RED, 630-90 nm) and near-infrared (NIR, 750-900 
$\mathrm{nm}$ ) bands are used. Zhang et al. (2006) used these spectral bands and NDVI respectively for the determination of the amount of nitrogen in rice, and Reyniers et al. (2006) observed dependence between the amount of nitrogen and NDVI in plants. Additionally, studies that evaluate convenience of various spectral bands in different plant growth phases or conditions were also made. Historical land cover is important for landscape planning (Marcucci, 2000), and remote sensing is a suitable tool for recognition of historical land cover (Ulbricht, Heckendorf, 1998; Gojda, 2000).

\section{Methods}

\section{Study site}

The project was solved on the land of University Agriculture Enterprise (UAE) (Mendel University in Brno), in

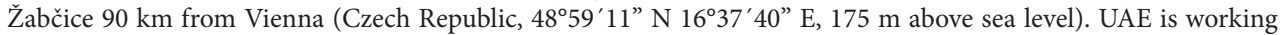
mainly in the maize area. Field production is focused on the production of cereals and fodder crops and livestock production is focused on beef and pig-raising. Additional activities are focused first of all on the practical aspects of the student education. UAE Žabčice controls 1602 ha of the farmland (1353 ha of the arable land).

In the area of interest from 1953 to 2003, there were significant changes between different categories of the land use. Area of the arable land decreased from $83 \%$ to $73 \%$, area of permanent grassland decreased from $7 \%$ to $2 \%$ and area of the forest land increased from 3\% to 5\%. The categories of orchards and gardens area increased by $7 \%$ and other categories by $6 \%$. The increase in the category of the others was mainly due to increase in built-up area.

Data processing

Modern digital aerial measuring cameras can capture the radiation from near-infrared band. Currently, the entire Czech Republic is already covered by digital infrared images. Aerial photos in the near-infrared band were used for visual interpretation of characters that identify the previous land cover. Visual identification was performed with digital images on the screen. The following were identified:

1. Pushing the borders of individual land cover categories.

2. Areas with different land cover.

3. Lines and distinctive shapes which differ from the surrounding area indicating different usage.

Identified differences were compared with historical source materials. The historical source materials are as follows:

1. Memories of witnesses and field survey.

2. Maps from II: military mapping from the years 1836-1852.

3. Maps from III: military mapping from the years $1877-1880$.

4. Cadastral maps since 1928.

5. Topographic maps since 1952.

6. Aerial photographs from the years 1953, 1968, 1976, 1984 and 1991.

\section{Results and discussion}

\section{Changes in the river bed and humidity conditions}

Investigated area is lowland and in the past river Šatava created meanders. The river straightened later and agricultural cultivated area increased. Soils in the original river bed and the waterlogged area have different physical and chemical properties. The present land use is limited by different soil properties. Remote sensing in the near-infrared band shows the historic river bed and waterlogged areas (Fig. 3). 


\section{Changes in forest area}

The whole area was forested in the ancient past. Deforestation began after the arrival of humans. The process of afforestation or deforestation of small areas continues even today. These processes form compact forest units and removed the small forest area. Deforested areas have different properties. Therefore, we can see the different areas in the near-infrared band (Fig. 4).

\section{Sand excavation}

Specifics of the area are locations where sand has been excavated. At first, sand was removed from the location where farming had taken place, and subsequently the remaining pit was filled with sludge from the nearby sugar refinery in Židlochovice, with the land then forested via volunteer seeding. When the area of arable land was increased in the 1970s, the land came under cultivation and was not reclaimed. Although it is used for agricultural purposes today, cultivation is not possible under adverse moisture conditions. Any other use is therefore practically impossible. The entire process has taken place without clear ownership relationships (Fig. 5).

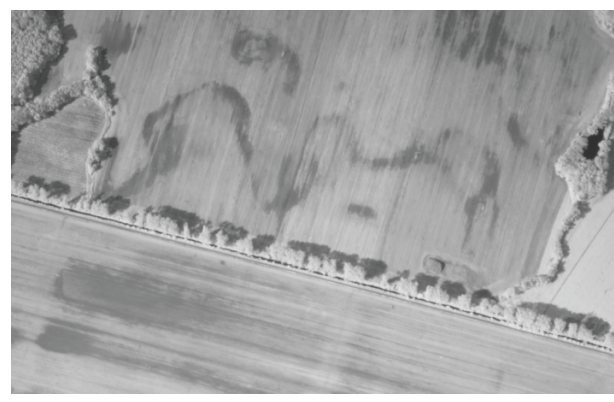

Fig. 3. Historic river bed.

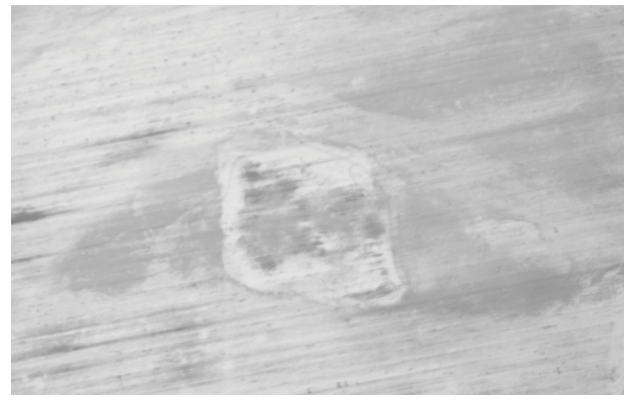

Fig. 5. Sand excavation. 


\section{Conclusion}

Aerial photos in the near-infrared band well identify the changes that are caused by different land cover earlier. Finding the origin of these differences in historical materials, we can determine the limits of today's land use and prevent unsuitable land use. This procedure is suitable as a background document for development of regional plans and design of the land consolidation.

\section{References}

Gojda, M. (2000). Archeologie krajiny. Praha: Academia.

Haboudane, D., Miller, J.R., Patey, E., Zarco-Tejada, P.J. \& Strachan I.B. (2004). Hypespaktral vegetation indices and novel algorihms for predicting green LAI of crop canopies: Modeling and validation in the context of precison agriculture. Remote Sens. Environ., 90, 337-352. DOI: 10.1016/j.rse.2003.12.013

Kubeš, J. (1996). Plánování venkovské krajiny. Praha: MŽP ČR.

Lipský, Z. (1999). Krajinná ekologie. Praha: Karolinum.

Reyniers, M., Vrindts, E. \& de Baerdemaeker J. (2006). Comparison of an aerial-based systém and an on the ground continuous measuring device to predict yield of winter wheat. Eur. J. Agron., 24(2), 87-94. DOI: 10.1016/j. eja.2005.05.002.

Zhang, P., Anderson, B., Tan, B., Huang, D. \& Myneni R. (2005). Potential monitoring of crop production using a satellite-based Climate-Variability Impact Index. Agric. For. Meteorol., 132(3-4), 344-358. DOI: 10.1016/j. agrformet.2005.09.004 